\title{
First Furongian (late Cambrian) trilobites from the Cantabrian Zone (north-western Spain)
}

\author{
Guillermo F. Aceñolaza, Roberto Albani, enrique BernárdeZ, Diego C. García-Bellido, \\ JUAN CARLOS GUTIÉRREZ-MARCO, ISABEL RÁBANO \& ARTUR A. SÁ
}

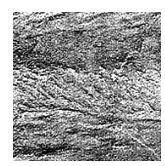

\begin{abstract}
The first Furongian trilobites are described herein from the Cambrian of the Cantabrian Zone, NW Spain. They were collected during the construction of the "Túnel Ordovícico del Fabar" from the shales of "El Fabar Beds" in the La Matosa member of the Barrios Formation. The assemblage includes the aphelaspidine genus Maladioidella, with a specimen identified as M. cf. colcheni, a species previously known from Sierra de la Demanda (Spain), and possibly Sardinia and Oman. Fragments of an indeterminate olenid trilobite and phyllocarid crustaceans have also been recorded. Based on the acritarch assemblage, these beds are considered as late Jiangshanian or earliest Stage 10 of the Cambrian System. The ichnofossil Cruziana semiplicata has also been collected in the tunnel from the upper part of the Ligüeria Member (Tremadocian) of the Barrios Formation, clearly postdating the occurrence of Maladioidella colcheni, its supposed tracemarker according to some authors. The separate record of both taxa (a Furongian trilobite and a Cambro-Ordovician trace fossil) does not support this statement, so their relationship would be refuted in this case. $\bullet$ Key words: Cambrian, Furongian, trilobites, trace fossils, Cantabrian Zone, Spain.
\end{abstract}

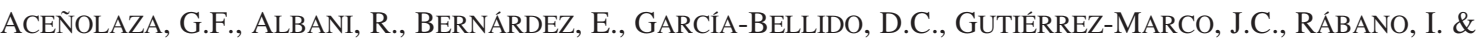
Sá, A.A. 2014. First Furongian (late Cambrian) trilobites from the Cantabrian Zone (north-western Spain). Bulletin of Geosciences 89(2), 239-244. Czech Geological Survey. Prague, ISSN 1214-1119. Manuscript received March 7, 2013; accepted in revised form August 2, 2013; published online March 11, 2014; issued May 19, 2014.

Guillermo F. Aceñolaza, Instituto Superior de Correlación Geológica (CONICET-UNT), Miguel Lillo 205, 4000 Tucumán, Argentina; gfacenolaza@gmail.com • Roberto Albani, Dipartimento di Scienze della Terra, Università di Pisa, Via S. Maria, 53-56126 Pisa, Italy; albani@dst.unipi.it • Enrique Bernárdez, Departamento de Geología, Universidad de Atacama, Avenida Copayapu 485, Copiapó, Atacama, Chile; enrique.bernardez@uda.cl Diego C. Garcia-Bellido, Sprigg Geobiology Centre, School of Earth \& Environmental Sciences, University of Adelaide, South Australia 5005 (Australia); Diego.Garcia-Bellido@adelaide.edu.au • Juan Carlos Gutiérrez-Marco, Instituto de Geociencias (CSIC, UCM), Facultad de Ciencias Geológicas, José Antonio Novais 2, 28040 Madrid, Spain; jcgrapto@geo.ucm.es • Isabel Rábano, Museo Geominero, IGME, Ríos Rosas 23, 28003 Madrid, Spain; i.rabano@igme.es•Artur A. Sá, Departamento de Geologia, Universidade de Trás-os-Montes e Alto Douro, Quinta de Prados-Apt. 1013, 5001-801 Vila Real, Portugal; asa@utad.pt
\end{abstract}

The Spanish record of late Cambrian trilobites is very sparse, being so far restricted to a few specimens occurring in the Najerilla Formation of the Sierra de la Demanda (Colchen 1967, Shergold et al. 1983) and the Valtorres, Valconchán and lowermost Borrachón formations of the western Iberian Chain (Shergold \& Sdzuy 1991, with earlier references). In the rest of the Mediterranean area, Furongian trilobites are also very rare, and only occur in scattered peri-Gondwanan sections from the southern Montagne Noire (SE France: Feist \& Courtessole 1984; Shergold et al. 2000; Álvaro et al. 2001, 2003), southwestern Sardinia (Italy: Loi et al. 1996), central Anti-Atlas (Morocco: Destombes \& Feist 1987, Geyer et al. 2002), and central Turkey (Shergold \& Sdzuy 1984).
In this note we report new record of late Cambrian trilobites from Spain, the first occurrence from the Cantabrian Zone of the Iberian Massif. The finds also have some palaeobiogeographical interest and regional biostratigraphic value.

\section{Geological setting}

The studied material comes from the so-called "El Fabar Beds", a thick intercalation of dark shale ( $c a 40 \mathrm{~m}$ ) recorded within the La Matosa Member of the Barrios Formation (Fig. 1B). This formation represents one of the most extensive and characteristic units of the Lower Palaeozoic succession of the Cantabrian Zone of the Iberian Massif 
(Aramburu \& García-Ramos 1993). The surprising discovery of shale beds yielding a relatively deep assemblage of shelly fossils, within a unit regarded by these authors as deposited exclusively in shallow water environments (Cruziana-sandstone facies), was only possible thanks to to the excavation of a tunnel for the Cantabrian Highway (A-8) in northern Spain, where the Cambrian-Ordovician succession was studied bed-by-bed by Gutiérrez-Marco \& Bernárdez (2003). The tunnel, later renamed as "Túnel Ordovícico del Fabar" due to the relevance of the scientific discoveries held in the Ordovician sequence (Fig. 1A), lies about $7 \mathrm{~km}$ west of the town of Ribadesella (Asturias region). From a geological point of view, it crosses the Laviana thrust-sheet of the Cantabrian Zone (Fig. 1A), an external zone of the Variscan Chain in the inner part of the Cantabrian-Asturian Arc (Pastor-Galán et al. 2011).

Two stratigraphically close fossiliferous horizons yielding trilobites and other fossil groups were discovered within the tunnel in one metre of fine grey and micaceous shale, in the lower half of the "El Fabar Beds". These strata grade upwards into coarser beds with sandy laminations and sporadic sandstone intercalations, the latter with diverse horizontal burrows. Most of the surface exposures of the "El Fabar Beds" (Fig. 1) correspond to this more sandy upper part, while the single outcrop of shales, located north-west of Alea, has so far proven unfossiliferous.

Macrofossils collected from both horizons during the excavation of the tunnel, belong to a single assemblage of obolid brachiopods, phyllocarid crustaceans and olenid trilobites. A palynological sample from the upper level yielded a rich and well-preserved acritarch association (Albani et al. 2006, 2007), composed of 19 taxa identified at the species level, and 7 more left in open nomenclature. Among them, the genera Acanthodiacrodium, Lusatia and Cristallinium are especially abundant, while the absence of Eliasum llaniscum Fombella 1977 was later highlighted by Palacios et al. (2009) as a significant indicator of a Furongian age for this assemblage. According to Albani et al. (2006), the El Fabar microflora might correspond to the lower part of Microflora RA5 from eastern Newfoundland (Parsons \& Anderson 2000), which can be correlated with the upper part of Microflora A4 of Martin in Martin \& Dean (1988) from the same area. The latter is placed in the Protopeltura praecursor trilobite biozone recognized in Avalonian Canada, Britain and Scandinavia, that has been considered either of late Jiangshanian age by Westrop et al. (2011, fig. 1) or as of earliest Cambrian Stage 10 age by Rushton et al. (2011, fig. 1).

\section{Fossil assemblage}

The record of late Cambrian trilobites from "El Fabar Beds" was briefly mentioned by Gutiérrez-Marco \& Ber- nárdez (2003) and Albani et al. (2006), but the material was never identified or studied in detail. For the present work, we have examined all the trilobite material collected during the excavation of the tunnel, consisting of various fragments of cranidia, librigenae and thoracic segments plus an articulated, yet poorly preserved, exoskeleton. From the material examined, two trilobite taxa can be recognized.

The most distinctive form is a semi-effaced subquadrate cranidium (Fig. 2A). The anterior margin is evenly curved and the posterior margin is straight. It has a truncated conical glabella, that is moderate short being $48 \%$ of the cranidial length (56\% of the length if the occipital ring is included) with barely visible glabellar furrows. The occipital ring is slightly wider transversely than the preoccipital glabellar width. The palpebral lobes are small (18.6\% of the cranidial length) and relatively widely spaced from each other (exsag.); their midpoints lie slightly forward of the glabellar midpoint. The frontal area is unequally divided, constituting $43.8 \%$ of the cranidial length. The preglabellar field is slightly shorter (sag.) than the anterior border (11.8\% cranidial length). However, due to tectonic deformation, the anterior border is completely flattened in the specimen, in contrast to the very low lateral profile of the remaining areas of the cranidium. The posterolateral projections of the fixigenae are triangular, with shallow posterior marginal furrows. A second cranidial fragment of the same size (Fig. 2B) as the previous one, displays similar characteristics and probably belongs to the same species.

The second trilobite is represented by a nearly complete specimen (Fig. 2C) and by several minute fragments of cranidia, showing a subrectangular and anteriorly rounded glabella, as well as librigenae with well-developed genal spines. The general outline and size of the articulated specimen closely resembles typical olenid genus Parabolina, but the poor preservation of the internal mould does not show the true tips of the librigenal spines, or the very typical macropleural spines on the $8^{\text {th }}$ thoracic segment.

From a taxonomical point of view, the first form is closely related to Maladioidella colcheni Shergold, Liñán \& Palacios 1983, a Furongian aphelaspidine trilobite originally described from the lowermost part of the Najerilla Formation of the Sierra de la Demanda, Spain (Shergold et al. 1983). It is probably also present in the Cabitza Formation of Sardinia (identified as Maladioidella cf. colcheni by Loi et al. 1996) and in the Andam Formation of the Arabian Peninsula (Fortey 1994).

Shergold et al. (1983) suggested a possible early Franconian age for the type horizon of $M$. colcheni in Spain, which was otherwise correlated with the Iverian or Sunwaptan regional stages by Álvaro et al. (2007). This range is similar to the occurrence of the genus Maladioidella in Wales, where it extends from the Parabolina 


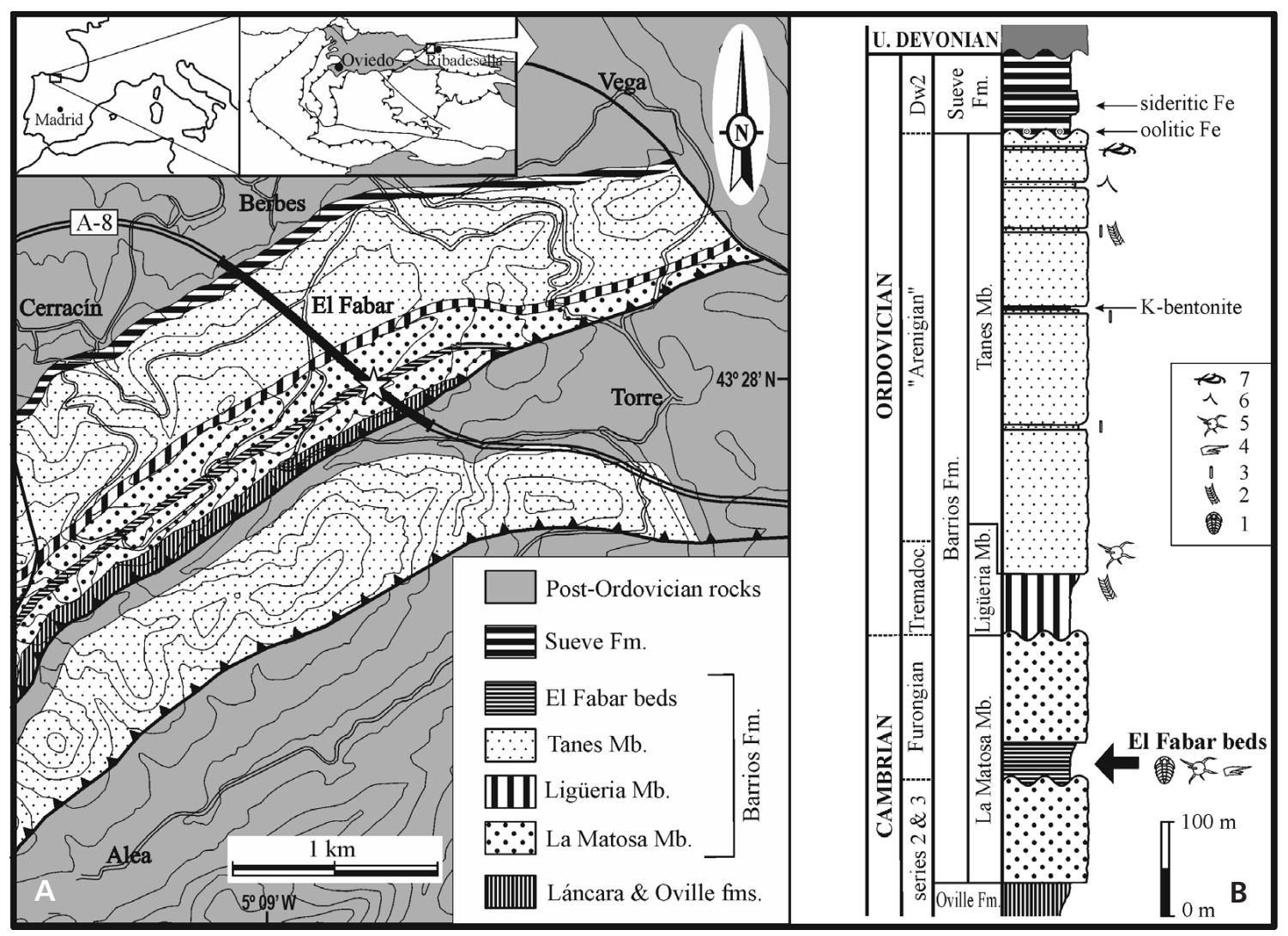

Figure 1. A - geological sketch map (Asturias, northern Spain) showing vertically dipping outcrops of the Barrios Formation in the north-eastern ends of the Laviana (W) and Rioseco nappes, and the path of the A8 Highway, including the El Fabar tunnel (thick black line). The star indicates the tunnel section through "El Fabar Beds". • B - the stratigraphic column summarizes the main units traversed by the tunnel, and significant beds and fossils occurring in the Barrios Formation: 1 - trilobites; 2 - Cruziana (trace fossil); 3 - Skolithos pipe-rock; 4 - phyllocarids; 5 - organic-walled microfossils; 6 - graptolites; 7 - lingulid shell bed. Adapted from Gutiérrez-Marco \& Bernárdez (2003, pp. 50 and 106).

spinulosa to the Peltura scarabaeoides trilobite zones (Rushton \& Hughes 1996), roughly equivalent to the Jiangshanian plus Stage 10 interval. In the Cantabrian Zone, the single record of $M$. cf. colcheni could be correlatable, by means of acritachs, with the Protopeltura praecursor trilobite biozone, assigned to the upper Jiangshanian or to the lower Cambrian Stage 10 by different authors (see above).

Olenid trilobites resembling Parabolina are yet unknown in peri-Gondwanan Europe or North Africa, besides the large paleogeographical distribution of the "Parabolina fauna" in the late Furongian (for references see Tortello \& Clarkson 2008 and Balseiro et al. 2011). However, the genus Parabolina itself was listed by Hammann in Hammann et al. (1982, p. 24) within a trilobite assemblage coming from the Borrachón Formation of the Iberian Chain that also includes the genera Angelina, Triarthrus, Hypermecaspis, Apatokephalus, Dikelokephalina, Pharostomina, Shumardia, Geragnostus and Leiagnostus. In Hammann's opinion, the trilobites of this formation are "very closely related to early Tremadocian faunas of South America", i.e., with the "Parabolina fauna" of Argentina and Mexico, largely coeval with conodonts of the Cordylodus proavus Zone. However, since the latter conodont biozone is restricted to the late Furongian Stage 10 after the official redefinition of the Cambrian/Ordovician boundary (Cooper et al. 2001), these trilobite beds are now regarded as late Cambrian instead of basal Ordovician age, and the system boundary has been moved upwards within the formation (Gutiérrez-Marco et al. 2002). However, similarities between the lower Borrachón trilobites and the late Furongian "Parabolina fauna" still needs confirmation (Shergold \& Sdzuy 1991, p. 201; Álvaro et al. 2007), because the preliminary review of the late Cambrian to early Ordovician trilobite assemblages from the Iberian Chains does not confirm the occurrence of Parabolina in the area either (J.J. Álvaro, pers. comm., 2011).

\section{Maladioidella as tracemarker}

A specimen of the trace fossil Cruziana semiplicata (Salter 1853) was collected in the tunnel from the upper part of the Ligüeria Member of the Barrios Formation (Fig. 2E), about 

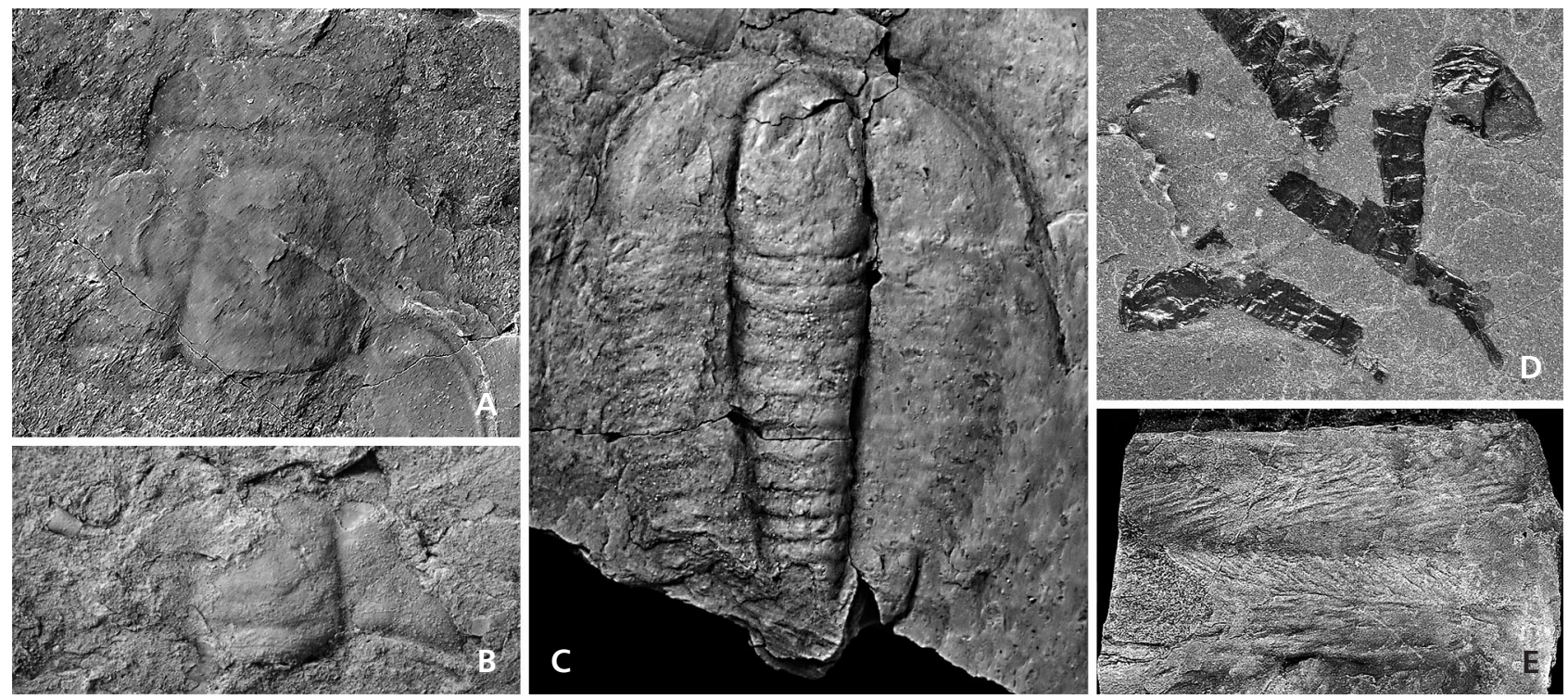

Figure 2. Furongian trilobites (A-C) and phyllocarid (D) specimens from "El Fabar Beds" (La Matosa Member), and Tremadocian trilobite trace fossil (E) from the Liguieria Member of the Barrios Formation, Túnel Ordovícico del Fabar. $\bullet$ - slightly tectonized cranidium of the idahoiid Maladioidella cf. colcheni Shergold, Liñán \& Palacios, 1983, associated with an unidentified librigena of a different species (lower right); MGM-175K, $\times 2.4$. - B - cranidial fragment of aphelaspidine trilobite, probably Maladioidella; MGM-176aK, $\times 2.6 . \bullet \mathrm{C}$ - articulated and almost complete dorsal carapace of a Parabolina-like olenid; MGM-177K, $\times 3.5 . \bullet \mathrm{D}$-fragments of indeterminate phyllocarid crustaceans, including two partially articulated carapaces with tails (lower left and upper right); MGM-172K, $\times 1.7$. $・$ E - Cruziana semiplicata Salter, 1853, showing the endopodal V-scratches (center), the exopodal "brushings" (in the outer margins) and the bordering ridges; MGM-1315O, $\times 0.75$. Original specimens housed in the Museo Geominero, Madrid.

$200 \mathrm{~m}$ above the occurrence of El Fabar trilobite assemblage and within early Ordovician strata. It has the typical morphology, with the median V-shaped scratches made by the endopodites (open in forward direction), the exopodal "brushings" in the parallel outer halves, as well as the marginal bordering ridges related to the pleural grooves.

According to Fortey \& Seilacher (1997), Furongian specimens of Cruziana semiplicata and body fossils of Maladioidella colcheni s.l. co-occur in almost the same beds from the Sierra de La Demanda and Oman, spreading over more than $2000 \mathrm{~km}$ of the Gondwanan margin. By considering other circumstantial evidence, such the similar width of the trilobite and the trilobite trace, which also displays the same "circling" behaviour, with prevailing sinistral curvatures in the two occurrences, they identified with little doubt the trilobite Maladioidella (of colcheni type) as the tracemarker of $C$. semiplicata. Moreover, the morphological match between the trilobite and trace strongly suggests Maladioidella as the tracemaker of C. semiplicata (Fortey \& Seilacher, 1997). Seilacher (2008, p. 38) even predicted the occurrence of M. colcheni in Asturias owing to the well-known record of its supposed trace in the Barrios Formation of the Cantabrian Zone (Seilacher 1970; Baldwin 1977, among others), and this is confirmed here by the first occurrence in the "El Fabar Beds" of the La Matosa Member. However, the single record of $C$. semiplicata from the tunnel section corresponds to early Ordovician strata (Ligüeria Member of the Barrios Formation), while aphelaspidine and related forms are not known to have survived the Cambrian. Due to these Tremadocian occurrences of $C$. semiplicata, Fortey \& Seilacher (1997, p. 111) suggest that it is likely that some other trilobite genus, morphologically similar to Maladioidella, may have been responsible for traces of the ichnospecies younger than Furongian. More recently, Jensen et al. (2011) plotted all the occurrences of $C$. semiplicata around Gondwana, Baltica, the Kara plate and Siberia, showing that a direct link between Maladioidella of colcheni type and $C$. semiplicata is not evident for the Sierra de la Demanda, where there is a considerable stratigraphic distance between the records of both fossils. Additionally C. semiplicata shows variations revealing a number of different limb morphologies among its producers, or even cases in which the supposed exopodite brushings and the endopodite scratches may result from the same leg branch made in different digging postures. Finally, Maladioidella and related forms are completely unknown among Furongian trilobite associations from Argentina, where C. semiplicata is fairly abundant (Aceñolaza \& Aceñolaza 2003, Mángano \& Buatois 2003).

With regards to the present identification of Maladioidella in the lower part of the Barrios Formation ( $\mathrm{La}$ Matosa Member), lateral occurrences of Furongian specimens of $C$. semiplicata in similar stratigraphic position are unknown from Asturias and are mainly located in the 
southern slope of the Cantabrian Cordillera in the León Province and from the Cabos Group of the West-Asturian-Leonese Zone (Baldwin 1977), more than $100 \mathrm{~km}$ away.

\section{Conclusions}

Furongian trilobites are very rare fossils in the whole periGondwanan Europe, Middle East and NW Africa. This is in part due to the absence of suitable marine facies for the preservation of shelly fossils (otherwise dominated by shallow water coarse siliciclastic sandstones), but mainly by the general lack of a Furongian sedimentary record. This involves major erosive unconformities and diachronic stratigraphic gaps, related to the denudation of rift shoulders during a multi-stage rifting, which is probably connected to the opening of the Rheic Ocean (Álvaro et al. 2007).

From a palaeobiogeographical point of view, the record in the Cantabrian Zone of a Parabolina-like olenid and Maladioidella cf. colcheni is of palaeobiogeographical interest, because the latter belongs to a singular group of trilobites that in the late Cambrian migrated into temperate, peri-Gondwanan platforms in intermediate paleolatitudinal settings. Also, according to Álvaro et al. (2007) this group includes Australasian invaders not only restricted to peri-Gondwanan margins, but also co-occurring with cosmopolitan genera like Maladioidella, Prochuangia, Onchonotellus, Olentella and others. The widespread genus Maladioidella has numerous local synonyms and "sister taxa" (Kuruktagella, Iranella, Cedarellus, Saratogia p.p., Elrathiella p.p., Lakella p.p., among others), and it has been recorded from Furongian siliciclastic and carbonate rocks extending from north Australia through South Korea and north China into Siberia, Artic Russia, Iran, Oman, Turkey and Europe (Spain, France, Sardinia and Wales): see Shergold et al. (1983), Shergold \& Sdzuy (1984), Fortey (1994), Rushton \& Hughes (1996), Rushton et al. (2002) and Álvaro et al. (2003).

\section{Acknowledgements}

To Fredrik Terfelt (Lund University, Sweden), Jorge Esteve (Nanjing Institute of Geology and Palaeontology, China) and Nigel Hughes (University of California, Riverside, USA) from their careful reviews and improvements on the manuscript. We are grateful to Javier Álvaro for information on the late Cambrian trilobites from the Borrachón Formation (Iberian Chains). We thank Carlos Alonso (Complutense University of Madrid) for photography. This is a contribution to Project CGL2009-07073 from the Spanish Ministry of Economy and Competitiveness (MINECO). G.F. Aceñolaza's research visit to Madrid in 2012 was funded by a grant from the Secretariat of University Policies (Argentina).

\section{References}

Aceñolaza, F. \& Aceñolaza, F.G. 2003. Ordovician trace fossils of Argentina, 177-193. In AcEÑOlaZA, F.G. (ed.) Aspects of the Ordovician System in Argentina. INSUGEO, Serie Correlación Geológica 6 (for 2002).

Albani, R., Bagnoli, G., Bernárdez, E., Gutiérrez-Marco, J.C. \& Ribecai, C. 2006. Late Cambrian acritarchs from the "Túnel Ordovícico del Fabar", Cantabrian Zone, N Spain. Review of Palaeobotany and Palynology 139, 41-52.

DOI 10.1016/j.revpalbo.2005.07.005

Albani, R., Bagnoli, G., Ribecai, C. \& Raevshaya, E. 2007. Late Cambrian acritarch Lusatia: Taxonomy, palaeogeography, and biostratigraphic implications. Acta Palaeontologica Polonica 52, 809-818.

Álvaro, J.J., Elicki, O., Geyer, G., Rushton, A.W.A. \& SherGOLD, J.H. 2003. Palaeogeographical controls on the Cambrian trilobite inmigration and evolutionary patterns reported in the western Gondwana margin. Palaeogeography, Palaeoclimatology, Palaeoecology 195, 5-35.

DOI 10.1016/S0031-0182(03)00300-6

Álvaro, J.J., Ferretti, A., GonZÁlez-Gómez, C., Serpagli, E., Tortello, M.F., Vecoli, M. \& Vizcaïno, D. 2007. A review of the Late Cambrian (Furongian) palaeogeography in the western Mediterranean region, NW Gondwana. Earth-Science Reviews 85, 47-81. DOI 10.1016/j.earscirev.2007.06.006

Álvaro, J.J., Lefebvre, B., Shergold, J.H. \& Vizcaïno, D. 2001. The Middle-Upper Cambrian of the southern Montagne Noire. Annales de la Société Géologique du Nord (2ème série) 8, 205-211.

Aramburu, C. \& García-Ramos, J.C. 1993. La sedimentación cambro-ordovícica en la Zona Cantábrica (NO de España). Trabajos de Geología 19, 45-73.

BALDWIN, C.T. 1977. The stratigraphy and facies associations of trace fossils in some Cambrian and Ordovician rocks from north-western Spain, 9-40. In CRIMES, T.P. \& HARPER, J.C. (eds) Trace fossil 2. Geological Journal, Special Issue 9.

Balseiro, D., Waisfeld, B.G. \& VAcCari, N.M. 2011. Paleoecological dynamics of Furongian (Late Cambrian) trilobitedominated communities from northwestern Argentina. Palaios 26, 484-499. DOI 10.2110/palo.2010.p10-152r

Colchen, M. 1967. Sur la présence du Cambrien supérieur à Prochuangia et à Chuangia dans la Sierra de la Demanda (Logroño), Espagne. Comptes Rendus de l'Académie des Sciences de Paris (série 2) 264, 1687-1690.

Cooper, R.A., Nowlan, G.S. \& Williams, S.H. 2001. Global Stratotype Section and Point for base of the Ordovician System. Episodes 24, 19-28.

Destombes, J. \& Feist, R. 1987. Découverte du Cambrien supérieur en Afrique (Anti-Atlas central, Maroc). Comptes Rendus de l'Académie des Sciences de Paris (série 2) 304, 719-724.

Feist, R. \& Courtessole, R. 1984. Découverte de Cambrien supérieur à trilobites de type est-asiatique dans la Montagne Noire (France Méridionale). Comptes Rendus de l'Académie des Sciences de Paris (série 2) 298, 177-182.

Fombella, M.A. 1977. Acritarcos de edad Cámbrico Medio-Inferior de la Provincia de León, España. Revista Española de Micropaleontología 9, 115-124. 
Fortey, R.A. 1994. Late Cambrian trilobites from the Sultanate of Oman. Neues Jahrbuch für Geologie und Paläontologie, Abhandlungen 194, 29-53.

Fortey, R.A. \& Seilacher, A. 1997. The trace fossil Cruziana semiplicata and the trilobite that made it. Lethaia 30, 105-112. DOI 10.1111/j.1502-3931.1997.tb00450.x

Geyer, G., Landing, E. \& Shergold, J.H. 2002. New data on the Upper Cambrian of Morocco. Programme and Abstracts, VII Conference of the Cambrian Stage Subdivision Working Group (ISCS), Caunes-Minervois, 18.

Gutiérrez-Marco, J.C. \& Bernárdez, E. 2003. Un tesoro geológico en la Autovía del Cantábrico. El Túnel Ordovícico del Fabar, Ribadesella (Asturias). 398 pp. Ministerio de Fomento, Madrid.

Gutiérrez-Marco, J.C., Robardet, M., Rábano, I., Sarmiento, G.N., San José Lancha, M.A., Herranz Araújo, P. \& Pieren PidAl, A.P. 2002. Ordovician, 31-49. In GibBons, W. \& MoRENO, T. (eds) The Geology of Spain. The Geological Society, London.

Hammann, W., Robardet, M. \& Romano, M. 1982. The Ordovician System in southwestern Europe (France, Spain and Portugal). Correlation Chart and Explanatory Notes. International Union of Geological Sciences Publication 11, 1-47.

Jensen, S., Bogolepova, O.K. \& Gubanov, A.P. 2011. Cruziana semiplicata from the Furongian (Late Cambrian) of Severnaya Zemlya Archipelago, Artic Russia, with a review of the spatial and temporal distribution of this ichnospecies. Geological Journal 46, 26-33. DOI $10.1002 /$ gj. 1248

Loi, A., Pillola, G.L. \& Leone, F. 1996. La limite CambrienOrdovicien dans le SW de la Sardaigne: relations avec des événements eustatiques globaux. Comptes Rendus de l'Académie des Sciences de Paris (série 2) 323, 881-888.

Mángano, M.G. \& Buatois, L.A. 2003. Trace fossils, 507-553. In Benedetto, J.J. (ed.) Ordovician fossils from Argentina. Secretaría de Ciencia y Tecnología-Universidad Nacional de Córdoba.

Martin, F. \& Dean, W.T. 1988. Middle and Upper Cambrian acritarch and trilobite zonation at Manuels River and Random Island, eastern Newfoundland. Geological Survey of Canada Bulletin 381, 1-91.

Palacios, T., Jensen, S., Barr, S.M. \& White, C.E. 2009. Acritarchs from the MacLean Brook Formation, southeastern Cape Breton Island, Nova Scotia, Canada: New data on Middle Cambrian-Lower Furongian acritarch zonation. Palaeogeography, Palaeoclimatology, Palaeoecology 273, 123-141. DOI 10.1016/j.palaeo.2008.12.006

Parsons, M.G. \& Anderson, M.M. 2000. Acritarch microfloral succession from the Late Cambrian and Ordovician (early Tremadoc) of Random Island, eastern Newfoundland, and its comparison to coeval microfloras, particularly those of the
East European Platform. American Association of Stratigraphic Palynologists, Contributions Series 38, 1-129.

Pastor-Galán, D., Gutiérrez-Alonso, G. \& Weil, A.B. 2011. Orocline timing through joint analysis: Insights form the Ibero-Armorican Arc. Tectonophysics 507, 31-46.

DOI 10.1016/j.tecto.2011.05.005

Rushton, A.W.A., Brück, P.M., Molyneux, S.G., Williams, M. \& WoodCock, N.H. 2011. A revised correlation of the Cambrian rocks in the British Isles. Geological Society Special Report 25, 1-62.

Rushton, A.W.A., Cocks, L.R.M. \& Fortey, R.A. 2002. Upper Cambrian trilobites and brachiopods from Severnaya Zemlya, Artic Russia, and their implications for correlation and biogeography. Geological Magazine 139, 281-290. DOI 10.1017/S0016756802006490

Rushton, A.W.A. \& Hughes, N.C. 1996. Biometry, systematics and biogeography of the Late Cambrian trilobite Maladioidella abdita. Transactions of the Royal Society of Edinburgh, Earth Sciences 86, 247-256. DOI $10.1017 / \mathrm{S} 0263593300007653$

SAlteR, J.W. 1853. On the lowest fossiliferous beds of north Wales. British Association for the Advancement of Science, Report for 1852, 56-68.

Seilacher, A. 1970. Cruziana stratigraphy of "non-fossiliferous" Palaeozoic sandstones, 447-476. In CRIMES, T.P. \& HARPER, J.C. (eds) Trace Fossils. Geological Journal Special Issue 3.

SeILACHER, A. 2008. Fossil Art. An exhibition of the Geologisches Institut, Tübingen University, Germany. 97 pp. CBM-Publishing, Laasby.

Shergold, J.H., Feist, R. \& Vizcaïno, D. 2000. Early Late Cambrian trilobites of Australo-Sinian aspect from the Montagne Noire, southern France. Palaeontology 43, 599-632. DOI 10.1111/1475-4983.00142

Shergold, J.H., Liñán, E. \& Palacios, T. 1983. Late Cambrian trilobites from the Najerilla Formation, north-eastern Spain. Palaeontology 26, 71-92.

Shergold, J.H. \& Sdzuy, K. 1984. Cambrian and early Tremadocian trilobites from Sultan Dag, central Turkey. Senckenbergiana lethaea $65,51-135$.

SherGold, J.H. \& SDZuY, K. 1991. Late Cambrian trilobites from the Iberian Mountains, Zaragoza Province, Spain. Beringeria 4, 193-235.

Tortello, F. \& Clarkson, E.N.K. 2008. Ontogeny, structure and moulting of Parabolina frequens argentina (Kayser) (Trilobita, Olenidae) from the Furongian of northwestern Argentina. Ameghiniana 45, 13-31.

Westrop, S.R., Adrain, J.M. \& Landing, E. 2011. The Cambrian (Sunwaptan, Furongian) agnostoid arthropod Lotagnostus Whitehouse, 1936, in Laurentian and Avalonian North America: systematics and biostratigraphic significance. Bulletin of Geosciences 86, 569-594. DOI 10.3140/bull.geosci.1256 